\title{
Alternatives to the Use of Fetal Bovine Serum: Serum-free Cell Culture
}

\author{
Gerhard Gstraunthaler \\ Department of Physiology, University of Innsbruck, A-Innsbruck
}

\section{Summary}

Serum is commonly used as a supplement to cell culture media. It provides a broad spectrum of macromolecules, carrier proteins for lipoid substances and trace elements, attachment and spreading factors, low molecular weight nutrients, and hormones and growth factors. The most widely used animal serum supplement is fetal bovine serum, FBS. Since serum in general is an ill-defined component in cell culture media, a number of chemically defined serum-free media formulations have been developed in the last two decades. Besides modern cell biological advances in cell and tissue culture and efforts towards a standardisation of cell culture protocols in Good Cell Culture Practice, in addition, considerable ethical concerns were raised recently about the harvest and collection of fetal bovine serum. Thus, in order to decrease the annual need for bovine fetuses in terms of the $3 R$ s through any reduction in the use or partial replacement of serum, as well as in terms of an improvement of cell and tissue culture methodology, serum-free cell culture represents a modern, valuable and scientifically well accepted alternative to the use of FBS in cell and tissue culture.
Zusammenfassung: Alternativen zur Verwendung von fötalem Kälberserum: die serum-freie Zellkultur

Serum ist ein weitverbreiteter Zusatz zu Zellkulturmedien. Es liefert ein breites Spektrum an Makromolekülen, Transportproteine für lipoide Substanzen und Spurenelemente, Bindungsproteine und Anheftungsfaktoren, niedermolekulare Nährstoffe, sowie Hormone und Wachstumsfaktoren. Das am häufigsten verwendete Serumsupplement ist fötales Kälberserum, FKS. Da Serum im Allgemeinen eine nur sehr unklar definierte Komponente in Kulturmedien darstellt, wurden in den letzten zwei Jahrzehnten eine Reihe von chemisch definierten, serum-freien Medien entwickelt. Neben den modernen zellbiologischen Fortschritten in der Zell- und Gewebekultur und den Bemühungen um eine Standardisierung von Zellkulturprotokollen im Sinne einer Good Cell Culture Practice, sind in den letzten Jahren auch sehr Ernst zu nehmende ethische Bedenken über die Gewinnung und Produktion von fötalem Kälberserum geäußert worden. Um im Sinne der berühmten $3 R$ s die jährlichen Verbrauchszahlen von Rinderföten durch eine Reduktion im Verbrauch bzw. dem Ersatz von Serum zu senken, wie auch im Sinne einer Verbesserung von Methodologien in der Zell- und Gewebekultur, stellt die serum-freie Zellkultur eine moderne, wissenschaftlich voll akzeptierte und abgesicherte Alternative zur Verwendung von FKS in der Zellkultur dar.

Keywords: cell and tissue culture, serum-free cell culture, in vitro, chemically defined media, alternatives to animal-derived products, replacement, 3R-principles, fetal bovine (calf) serum, vegetal serum, animal welfare

\section{Introduction}

Cell and tissue culture, i.e. the propagation and cultivation of cells in vitro (for definitions, see Tab. 1) (Schaeffer, 1990), has become an indispensable tool in biomedical sciences. The use of cell culture is increasing exponentially, and new in vitro alternatives are constantly being developed.

The increased use of in vitro methodologies in basic research and applied biomedical sciences - in cell biology, physiology, pharmacology, and toxicology - is indeed a beneficial development in terms of the $3 \mathrm{R}$ concept of Russel and
Burch (Balls et al., 1995), decreasing the number of experimental animals. In addition, during the past decade, invertebrate cell and tissue culture has gained an increasingly prominent role in basic cell and molecular biological research, since cultured insect cells are widely used as eukaryotic in vitro expression systems using baculovirus expression vectors (Fraser, 1992; Jarvis, 1991).

However, in most cases, routine cell and tissue culture demands the use of animal-derived products, mainly fetal bovine serum (FBS), as culture medium constituents (see below).
The amount of FBS produced for the world market is estimated at approximately 500.000 litres per year. This means, that more than 1.000 .000 bovine fetuses have to be harvested, and it is expected, that these numbers will continue to increase annually (Jochems et al., 2002; Shah, 1999). Recently, serious ethical concerns were raised with regard to the welfare of the donor fetuses in the harvest, production and processing of FBS (Shailer and Corrin, 1999; van der Valk et al., 2003). The concerns focused mainly on the current methods of collecting FBS that may cause suffering to the animals, in particular to fetuses. In brief, the bovine fetuses, from which blood is 
Tab. 1: The definitions of cell and tissue culture according to Schaeffer, 1990.

Cell culture: . . . the maintenance or cultivation of human or animal cells in vitro including the culture of single cells. In cell cultures, the cells are no longer organised into tissues.

Tissue culture: The maintenance or growth of tissues, in vitro, in a way that may allow differentiation and preservation of their architecture and/or function. drawn for FBS production, are obtained from pregnant cows sent to slaughter. In huge meat cattle herds, bulls and cows roam freely together, and as a result, many cows are pregnant at the time of slaughter. When a pregnant cow is discovered in the slaughterline, the fetus is separated at the abattoir, and fetal blood is collected under aseptic conditions. This is usually performed by cardiac puncture. Alternatively, fetal blood may be harvested by means of umbilical vein puncture or puncture of the jugular vein (Jochems et al., 2002).

These aspects were the topic of a recent workshop entitled "Towards Better In Vitro Methods: The Replacement of Fetal Bovine Serum", and the reader is referred to the comprehensive workshop report (van der Valk et al., 2003). Thus, any efforts to decrease the global demands for FBS and thus to decrease the number of bovine fetuses required should be welcomed and supported.

\section{The basics in cell and tissue culture}

For successful growth and maintenance of human or animal cells in vitro, either primary cultures or continuous cell lines, appropriate culture conditions are required that mimic the physiological conditions in vivo et situ with respect to temperature, $\mathrm{pH}$, osmolarity, and oxygen supply (Davis, 2002; Masters, 2000). The microenvironment of a cell, depicted schematically in Fig. 1, must therefore be provided: by the culture substratum, i.e. the appropriate culture dish or specifically coated surfaces, that allow attachment and spreading of cells (the contact environment), and by the culture medium, which represents the diffuse environment. The latter comprises all types of soluble molecules - nutrients and salts, hormones and growth factors (Freshney, 1994).

Thus it is obvious, that the culture medium is by far one of the most important single factors in cell and tissue culture. The culture medium must supply all essential nutrients for cell metabolism, growth and proliferation (Bettger and McKeehan, 1986; Butler and Jenkins, 1989; Ham and McKeehan, 1979; Levintow and Eagle, 1961; Nardone, 1987). These include biosynthetic precursors for cell anabolism, catabolic substrates for energy metabolism, vitamins and trace elements whose function is primarily catalytic, and bulk inorganic ions (electrolytes) whose functions are both catalytic and physiological, e.g. to maintain culture medium $\mathrm{pH}$ and osmo- larity within acceptable limits. In addition, animal serum is frequently added to chemically defined basal media.

\section{The role of serum in cell culture media}

The supplementation of basal culture media with animal serum of different origin is essential for cell growth and for the stimulation of proliferation ("mitogenic effect"). The sera used most widely are from adult or newborn animals, or of fetal bovine origin. Whole animal serum as well as fetal bovine serum (FBS), in general, is an extremely complex mixture of a large number of constituents, low and high molecular weight biomolecules with different, physiologically balanced growth-promoting and growth-inhibiting activities. The role of serum in cell culture media is summarised in Tab. 2.

Contemporary knowledge in modern cell biology and biochemistry allowed the identification of the (growth) factors involved in in vivo processes, like cell proliferation and tissue repair (e.g. in wound healing), and cell maturation and differentiation (e.g. embryonic maturation, stem cell lineage, epithelial differentiation, etc.). The major functions of serum in culture media are to provide (i) hormonal factors stimulating cell growth and proliferation, and promoting differentiated functions, (ii) transport proteins

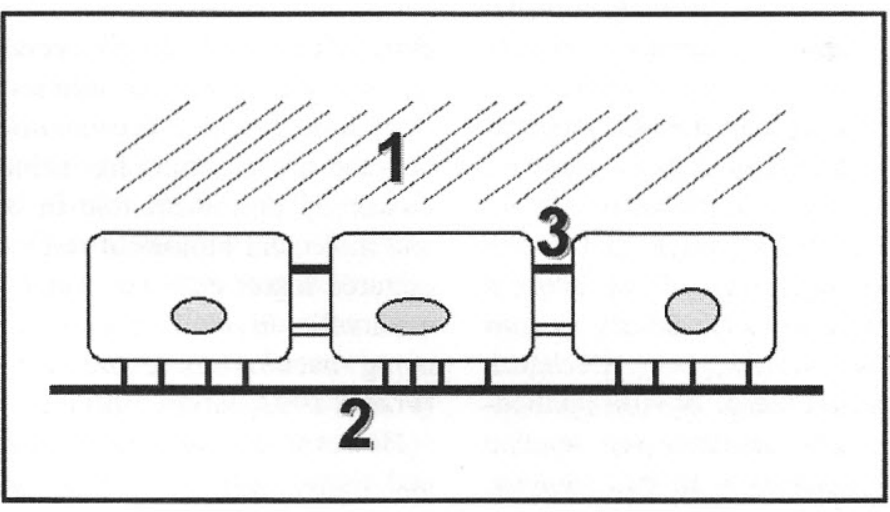

Fig. 1. Parts of the microenvironment of the mammalian cell regulating its behaviour in vivo and in vitro. (1) The diffuse environment, which in cell cultures is solely provided by the culture medium, (2) the contact environment (cell-matrix adhesion), and (3) the junctional connections between neighbouring cells (cell-cell adhesion). 
Tab. 2: The role of serum in cell culture media (Davis, 2002; Freshney, 1994; Lindl, 2002; Masters, 2000).

\title{
Role of Serum in Cell Culture Media
}

\author{
Serum provides \\ $>$ growth factors and hormones \\ $>$ binding and transport proteins \\ $>$ attachment- and spreading factors \\ $>$ additional amino acids, vitamins and trace elements \\ $>$ fatty acids and lipids \\ $>$ protease-inhibitors \\ $>$ 'detoxification' (due to binding and inactivation) \\ $>$ (colloid)osmotic pressure (serum-free vs. protein-free)
}

carrying hormones (e.g. transcortin), minerals and trace elements (e.g. transferrin), and lipids (e.g. lipoproteins), (iii) attachment and spreading factors (i.e. components of the extracellular matrix), and (iv) stabilising and detoxifying factors, needed to maintain $\mathrm{pH}$ or to inhibit proteases either directly, such as $\alpha$-antitrypsin or $\alpha 2$-macroglobulin, or indirectly, by acting as an unspecific sink for proteases and other (toxic) molecules (Tab. 2).

It is a well known fact that natural clot serum is more effective than plasma in stimulating cell proliferation. This appears to be due to the release of certain polypetides from activated platelets during the clotting process.

In recent decades, a number of growth factors, hormones, transport proteins, cofactors, and essential minerals and trace elements have been identified, that all drive specific gene expression, initiate and control the cell cycle and thus cell division, and program specific cell differentiation (Hill and Treisman, 1995). We know today, for example, that a specific transcriptional activation program is needed to initiate cell growth and proliferation in vitro, e.g. the specific activation of mitogen-activated protein (MAP) kinases, like the extracellular signal-regulated kinase (ERK) cascade (Denhart, 1996; Kyriakis and Avruch, 2001; Widmann et al., 1999), by epidermal growth factor (EGF) (Carpenter and Cohen, 1979; Cohen, 1987) or plateletderived growth factor (PDGF) (Heldin et al., 1985; Ross et al., 1986). Other polypeptide growth factors which are present in animal serum and activate cultured cells with varying degrees of specificity are fibroblast growth factor (FGF) (Gospodarowicz et al., 1987), nerve growth factor (NGF) (Levi-Montalcini, 1987), endothelial growth factor, or insulin-like growth factors IGF-1 and IGF-2 (Deuel, 1987).

Because of its rich content of growth factors and its low gamma-globulin content, FBS has become the standard supplement of cell culture media. In most cases, FBS is used at concentrations of $10 \%(\mathrm{v} / \mathrm{v})$, although this may vary for specific applications (e.g. low serum media). Other advantages in the use of FBS include the following: (i) FBS is a cocktail of most of the factors required for cell proliferation and maintenance (see above), (ii) it is thus an almost universal growth supplement effective in most types of human and animal (including insect) cells. (iii) Using serumsupplemented medium therefore reduces the need to spend time and effort developing a specific, optimised medium formulation for each cell type.

However, the use of animal serum in cell culture also bears a number of disadvantages (Lindl, 2002; van der Valk et al., 2003): (i) serum is an ill-defined medium supplement, and thus an ambiguous factor in cell culture (Bjare, 1992), (ii) serum batches display quantitative and qualitative variations in their composition, and thus introduce a significant lot-to-lot variability (Price and Gregory, 1982) (Tab. 3), (iii) serum may contain different amounts of endotoxins, haemoglobin, and other adverse factors, and (iv) serum can be a potential source of microbial contaminants, such as fungi, bacteria, viruses or prions (Dormont, 1999; Eliot, 1999; Wessman and Levings, 1999).

Thus, serum introduces several unknown variables into the tissue culture system. In addition, serum-supplemented media may be unable to support growth of specific cell types, and in primary cultures of highly differentiated epithelial cells, serum may be unable to prevent the overgrowth of the culture by fibroblasts. Therefore, in terms of standardised protocols in Good Cell Culture Practice (Hartung et al., 2002), it might be worthwhile to omit the supplementation of culture media with animal sera.

\section{Alternatives to fetal bovine serum in cell and tissue culture}

The removal of serum from the cell culture medium and/or the replacement with other complex biological fluids and extracts initiates multifarious variations in the interactive nature of the cell culture system that are introduced in a

Tab. 3: Variation profile of fetal bovine sera (Price and Gregory, 1982).

\begin{tabular}{|c|c|c|}
\hline \multicolumn{3}{|c|}{$\begin{array}{l}\text { Composition of } \\
\text { Fetal Bovine Serum }\end{array}$} \\
\hline Components & Conc. & Range \\
\hline $\begin{array}{l}\text { total protein } \\
\text { albumin }\end{array}$ & $\begin{array}{l}3.8 \mathrm{~g} / 100 \mathrm{ml} \\
2.3 \mathrm{~g} / 100 \mathrm{ml}\end{array}$ & $\begin{array}{l}3.2-7.0 \\
2.0-3.6\end{array}$ \\
\hline $\begin{array}{l}\text { endotoxin } \\
\text { haemoglobin }\end{array}$ & $\begin{array}{c}0.36 \mathrm{ng} / \mathrm{ml} \\
11.3 \mathrm{mg} / 100 \mathrm{ml}\end{array}$ & $\begin{array}{c}0.01-10.0 \\
2.4-18.1\end{array}$ \\
\hline $\begin{array}{l}\text { cholesterol } \\
\text { fatty acids } \\
\text { phospholipids } \\
\text { triglycerides }\end{array}$ & $\begin{array}{c}31 \mathrm{mg} / 100 \mathrm{ml} \\
\mathrm{mg} / \mathrm{ml}\end{array}$ & $12-63$ \\
\hline glucose & $125 \mathrm{mg} / 100 \mathrm{ml}$ & $85-247$ \\
\hline $\begin{array}{l}\text { insulin } \\
\text { cortisone } \\
\text { trijodo-thyronine } \\
\text { thyroxine } \\
\text { PTH }\end{array}$ & $\begin{array}{c}10 \mu \mathrm{U} / \mathrm{ml} \\
0.5 \mu \mathrm{g} / 100 \mathrm{ml} \\
119 \mathrm{ng} / 100 \mathrm{ml} \\
12.1 \mathrm{ng} / 100 \mathrm{ml} \\
1718 \mathrm{pg} / \mathrm{ml}\end{array}$ & $\begin{array}{c}6-14 \\
<0.1-2.3 \\
56-223 \\
7.8-15.6 \\
85-6180\end{array}$ \\
\hline $\begin{array}{l}\text { PGE } \\
\text { PGF }\end{array}$ & $\begin{array}{c}5.91 \mathrm{ng} / \mathrm{ml} \\
12.33 \mathrm{ng} / \mathrm{ml}\end{array}$ & $\begin{array}{l}0.5-30.5 \\
3.8-42.0\end{array}$ \\
\hline
\end{tabular}


single step. A poorly defined medium supplement (FBS) is replaced by another ill-defined product. Nevertheless, methods to reduce the requirements for FBS in culture media as well as alternative animal serum substitutions were recently described (Jayme et al., 1988). The latter include substitution with newborn or adult calf sera, or the use of sera from other animal species (horse, pig, goat, etc.). Other animal-derived alternatives are tissue extracts (e.g. pituitary extracts, chicken embryo extracts), bovine milk fractions, or bovine colostrum (Belford et al., 1995; Klagsbrun, 1980; Pakkanen and Neutra, 1994; Steimer et al., 1981). Most recently, protein fractions from plant extracts, called vegetal serum, were successfully introduced to grow and maintain epithelial cells in culture (Hartung et al., 2003). Additional methods of choice to reduce FBS requirement include (i) the optimisation of existing culture media, (ii) the use of reduced serum media, or (iii) the design of serumfree, chemically defined media (Barnes and Sato, 1982b; Froud, 1999; Gstraunthaler, 2001).

\section{Serum-free cell culture}

Today, the importance of culturing mammalian cells in medium without serum supplementation is widely recognised (Bjare, 1992; McKeehan et al., 1990). With the identification, cloning, and recombinant production of essential growth factors and nutrients required by different cell types (Barnes et al., 1987), a broad selection of chemically defined, serum-free media for continuous cell lines as well as for specific cell types in primary culture has been designed and is available (Barnes and Sato, 1980a, 1980b; Bottenstein et al., 1979; Froud, 1999; Merten, 1999; Taub, 1990).

From the disadvantages in the use of FBS in culture media, as listed above, the advantages and benefits of serum-free media are easily deducible: (i) chemically defined and controlled culture conditions in vitro, (ii) reduced variability in qualitative and quantitative culture medium composition, (iii) elimination of a potential source of microbial contamination (Froud, 1999; Merten, 1999), (iv) advantages in down-stream processing (i.e. the

Tab. 4: Cell physiological arguments for serum-free cell culture.

\begin{tabular}{|c|}
\hline $\begin{array}{c}\text { Cell Physiological Arguments } \\
\text { for Serum-free Cell Culture }\end{array}$ \\
\hline - defined and controlled culture conditions in vitro: \\
$>$ defined synthetic or recombinant media constituents \\
$>$ exact control of physiological action \\
(synergistic, antagonistic effects of hormones and factors) \\
$>$ studies on hormonal and nutritional requirements of cells \\
(autocrine, paracrine loops) \\
$>$ isolation (selection) of specific cell types
\end{tabular}

isolation of cell culture products), and (v) most of all, ethical aspects, i.e. reduction of the worldwide use of FBS and thus the numbers of bovine fetuses used as source of FBS (Jochems et al., 2002; van der Valk et al., 2003).

Serum-free media are generally more cell-specific. Thus, for basic research in cell physiology, additional benefits in the use of serum-free media can be defined (Tab. 4) (Barnes et al., 1987).

Serum-free media formulations for the initiation of primary cultures of specific cell types, as well as for culturing continuous cell lines, are published in increasing number (Barnes and Sato, 1980a; Taub, 1990) and their commercial availability is increasing steadily (Defrancesco, 1998). Therefore, one key step towards the use or the development of a serum-free formulation for a desired cell type and/or cell line may include a review of the published literature, scanning of commercial catalogues, and contacting other laboratories working in similar fields in order to determine whether a suitable media formulation for a specific cell line might already exist. Most recently, important initiatives were started aiming to establish searchable data banks containing all serum-free media formulations that have been published for the initiation of specific primary cultures and the maintenance of continuous cell lines, respectively (Falkner et al., 2003; Fischer et al., 2001; Strebel and Fischer, 2003).

Based on the pioneering work of Sato and coworkers (Barnes and Sato, 1980a, 1980b), a basal medium for serum-free cell culture was established, consisting of a 50:50 (v/v) mixture of Dulbecco's Modified Eagle's Medium (DMEM), that supplies all essential nutrients in sufficient quantities, and the highly enriched Ham's F-12 Nutrient Mixture. Other highly enriched media which have been developed for serum-free culture are media of the $M C D B$ (Molecular, Cellular and Developmental Biology, University of Colorado) series, CMRL 1066 and CMRL 1415 (Connaught Medical Research Laboratories) media, or NTCT 135 (National Cancer Institute, Tissue Culture Section) medium (Ham and McKeehan, 1979; Morton, 1970).

The basic medium (DMEM/Ham F-12) is then supplemented with specific factors, like hormones and growth factors, fatty acids and lipids, and vitamins and trace elements (Taub, 1990). In addition, due to the lack of attachment and spreading factors in serum-free medium formulations, a precoating of culture vessels with components of the extracellular matrix is required for some cells (Kleinman et al., 1987). During the last decades it turned out that for most cell lines the supplementation of DMEM/Ham F-12 with insulin, transferrin and selenium is an obligatory requirement. Insulin is essential for glucose transport into cultured cells. It is added at relatively high concentrations $(1-10 \mu \mathrm{g} / \mathrm{ml})$ due to its rapid loss in bioactivity. Insulin and its degradation products may also mimic the growth-stimulatory activity of related peptides, like insulin-like growth factors (IGF) and somatomedins. Transferrin is a serum protein that is responsible for cellular iron transport. Among the trace 
elements, selenium, added as sodium selenite, seems to be important as cofactor of selenium-dependent enzymes, like glutathione reductase and glutathione peroxidase, catalyzing glutathione metabolism and turnover. Based on this knowledge, ITS - insulin-transferrinselenite - is commercially available as an universal medium supplement. Other hormones used in serum-free cell culture are parathyroid hormone, glucocorticoids (e.g. hydrocortisone, dexamethasone), thyroid hormones (triiodothyronine), glandotropic factors, like thyroid-stimulating hormone, adrenocorticotropin, or follicle-stimulating hormone, and estrogens (e.g. estradiol). Most commonly used growth factor ingredients are EGF, FGF, NGF, and PDGF, mostly available as recombinant peptides. Furthermore, small lipid preparations as well as essential unsaturated fatty acids and ethanolamine have to be added, which can be purchased in water-soluble form. The present "stateof-the-art"-technologies in serum-free cell culture are summarised in Tabs. 5-8.

Serum-free media are highly cell specific. Therefore, for a certain cell line serum-free medium formulations have to be developed on an individual basis. For example, serum-free media for the different cell types lining the mammalian nephron - proximal tubular cells, thick ascending limb cells, distal tubular and collecting duct cells - have been elaborated (Sens et al., 1999; Taub and Sato, 1980). Based upon the fact that renal tubular epithelial cells differ substantially in their metabolic properties (Wirthensohn and Guder, 1986) and hormone receptor expression profile (Morel, 1981), nephron-specific, chemically defined, serum-free media could be designed (Chung et al., 1982; Taub, 1990; Wang and Taub, 1991; Wilson and Horster, 1983). In addition, serum-free media for growth and maintenance of the most widely used renal epithelial cell lines LLC-PK 1 , MDCK and OK (Gstraunthaler, 1988) are described (Chuman et al., 1982; Leiderman et al., 1989; Taub et al., 1979). It was noted, that for optimal growth an adenylate cyclase-stimulating hormone was required: vasopressin for the LLC-PK 1 cell line, and prostaglandin $\mathrm{E}_{1}$ in case of MDCK cells. The cAMPgenerating hormones could be replaced by dibutyryl-cAMP, a cell-permeable derivative, or by the phosphodiesterase inhibitor isobutyl methylxanthine (IBMX), inhibiting intracellular cAMP breakdown (Taub, 1990). Also cholera toxin was successfully introduced for culturing rat proximal tubule cells under serum-free conditions (Hatzinger and Stevens, 1989). Thus, elevated cellular cAMP levels are essential for growth and proliferation. Obviously, cAMP-regulated protein kinase A, together with activated MAP kinases, may play a crucial role in regulating $\mathrm{G1}$-cyclins and $\mathrm{G} 1$ to $\mathrm{S}$

Tabs. 5-8: Contemporary "state-of-the-art"-technologies in serum-free cell and tissue culture.

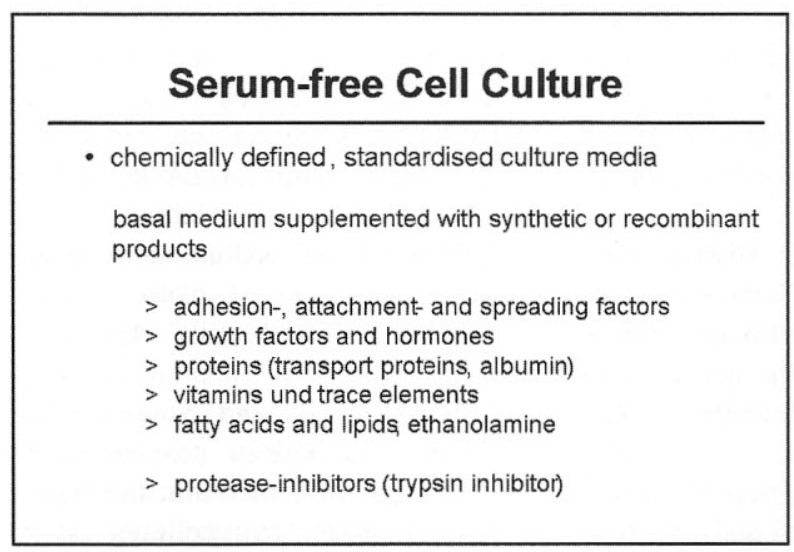

\begin{tabular}{|c|c|}
\hline \multicolumn{2}{|c|}{ Serum-free Cell Culture (3): „state-of-the-art" } \\
\hline hormones & $\begin{array}{l}\text { insulin } \\
\text { hydrocortisone, dexamethasone } \\
\text { trijodo-thyronine, thyroxine } \\
\text { progesterone, estradiol } \\
\text { prolactin } \\
\text { glucagon } \\
\text { vasopressin } \\
\text { PTH } \\
\text { prostaglandins }\end{array}$ \\
\hline
\end{tabular}

\begin{tabular}{|c|c|}
\hline \multicolumn{2}{|c|}{ Serum-free Cell Culture (2): „state-of-the-art“ } \\
\hline basal medium & DMEM/Ham's F-12 (50:50) \\
\hline adhesion factors & $\begin{array}{l}\text { coating of culture vessels } \\
\text { with collagen (type I, type IV) } \\
\text { fibronectin } \\
\text { laminin etc }\end{array}$ \\
\hline growth factors & $\begin{array}{l}\text { epidermal growth factor (EGF) } \\
\text { fibroblast growth factor (FGF) } \\
\text { platelet-derived growth factor (PDGF) } \\
\text { nerve growth factor (NGF) } \\
\text { insulin-like growth factor (IGF) }\end{array}$ \\
\hline & cytokines (interferons, interleukins) \\
\hline
\end{tabular}

\begin{tabular}{|ll|}
\hline Serum-free Cell Culture (4): ,state-of-the-art“" \\
\hline proteins & $\begin{array}{l}\text { bovine serum albumin } \\
\text { transferrin } \\
\text { vitamins }\end{array}$ \\
vitamin A-derivatives: retinoic acid \\
face elements & $\begin{array}{l}\text { sodium selenite } \\
\text { facetate }\end{array}$ \\
& $\begin{array}{l}\text { linoleic acid, oleic acid } \\
\text { cholesterol, phospholipids } \\
\text { ethanolamine }\end{array}$ \\
\hline
\end{tabular}


phase transition in the cell cycle (Murray and Hunt, 1993).

Meanwhile, a vast array of serum-free media for the culture of almost all cell types have been described, and are summarized elsewhere (Barnes and Sato, 1980a, 1980b; Bjare, 1992; Bottenstein et al., 1979; Taub, 1990; Zimmerman et al., 2000). Moreover, as mentioned above, databases are to be established, making available all serum-free medium formulations in a searchable format (Falkner et al., 2003; Fischer et al., 2001; Strebel and Fischer, 2003).

In summary, growing cells in serumfree media has many advantages, first of all in terms of the 3 Rs, i.e. the decrease in the annual numbers of bovine fetuses due to the reduction in, or the partial replacement of serum, as well as in terms of improvements in cell and tissue culture methodologies, and secondly, for cell biological reasons, since the high specificity of serum-free media allows the selection of certain cell types, and their specific stimulation and differentiation, although the ideal general-purpose serum-free medium has not yet been developed and is almost certainly an unattainable goal.

\section{References}

Balls, M., Goldberg, A. M., Fentem, J. H. et al. (1995). The three Rs: the way forward. The report and recommendations of ECVAM Workshop 11. ATLA 23, 838-866.

Barnes, D. and Sato, G. (1980a). Methods for growth of cultured cells in serum-free medium. Anal. Biochem. 102, 255-270.

Barnes, D. and Sato, G. (1980b). Serumfree cell culture: a unifying approach. Cell 22, 649-655.

Barnes, D., McKeehan, W. L. and Sato, G. H. (1987). Cellular Endocrinology: Integrated physiology in vitro. In Vitro Cell. Dev. Biol. 23, 659-662.

Belford, D. A., Rogers, M.-L., Regester, G. O. et al. (1995). Milk-derived growth factors as serum supplements for the growth of fibroblasts and epithelial cells. In Vitro Cell. Dev. Biol. 31, 752-760.

Bettger, W. J. and McKeehan, W. L. (1986). Mechanisms of cellular nutri- tion. Physiol. Rev. 66, 1-35.

Bjare, U. (1992). Serum-free cell culture. Pharmac. Ther. 53, 355-374.

Bottenstein, J., Hayashi, I., Hutchings, S. et al. (1979). The growth of cells in serum-free hormone-supplemented media. Methods Enzymol. 58, 94-109.

Butler, M. and Jenkins, H. (1989). Nutritional aspects of the growth of animal cells in culture. J. Biotechnol. 12, 97 110.

Carpenter, G. and Cohen, S. (1979). Epidermal growth factor. Annu. Rev. Biochem. 48, 193-216.

Chuman, L., Fine, L. G., Cohen, A. H. and Saier, M. H. (1982). Continuous growth of proximal tubular kidney epithelial cells in hormone-supplemented serum-free medium. J. Cell Biol. 94, 506-510.

Chung, S. D., Alavi, N., Livingston, D. et al. (1982). Characterization of primary rabbit kidney cultures that express proximal tubule functions in a hormonally defined medium. J. Cell Biol. 95, 118-126.

Cohen, S. (1987). Epidermal growth factor. In Vitro Cell. Dev. Biol. 23, 239-246.

Davis, J. M. (2002). Basic Cell Culture. A Practical Approach. $2^{\text {nd }}$ Ed., Oxford University Press.

Defrancesco, L. (1998). Serum-free cell culture: from art to science in 25 years. The Scientist 12, 19-24.

Denhart, D. T. (1996). Signal-transducing protein phosphorylation cascades mediated by Ras/Rho proteins in the mammalian cell: the potential for multiplex signalling. Biochem. J. 318, 729-747.

Deuel, T. F. (1987). Polypeptide growth factors: roles in normal and abnormal cell growth. Апnи. Rev. Cell Biol. 3, 443-492.

Dormont, D. (1999). Transmissible spongiform encephalopathy agents and animal sera. Dev. Biol. Stand. 99, 25-34.

Eliot, M. (1999). Risks of virus transmission associated with animal sera or substitutes and methods of control. Dev. Biol. Stand. 99, 9-16.

Falkner, E., Schöffl, H., Appl, H. et al. (2003). Replacement of sera for cell culture purposes: a survey. ALTEX 20, 167.

Faser, M. J. (1992). The baculovirus-infected insect cell as a eukaryotic gene expression system. Curr. Top. Microbiol. Immunol. 158, 131-172.

Fischer, R. W., Messi, F., Umena, P. et al. (2001). Welche Zelllinien können in definiertem synthetischen Medium kultiviert werden? Ein ambitioniertes Projekt - Aufruf zur Zusammenarbeit. ALTEX 18, 200.

Freshney, R. I. (1994). Culture of Animal Cells. A Manual of Basic Technique. $3^{\text {rd }}$ Ed., New York: Wiley-Liss, Inc.

Froud, S. J. (1999). The development, benefits and disadvantages of serumfree media. Dev. Biol. Stand. 99, 157166.

Gospodarowicz, D., Ferrara, N., Schweigerer, L. and Neufeld, G. (1987). Structural characterization and biological functions of fibroblast growth factor. Endocrine Rev. 8, 95114.

Gstraunthaler, G. J. A. (1988). Epithelial cells in tissue culture. Renal Physiol. Biochem. 11, 1-42.

Gstraunthaler, G. (2001). Serumfreie Zellkultur. ALTEX 18, 183.

Ham, R. G. and McKeehan, W. L. (1979). Media and growth requirements. Methods Enzymol. 58, 44-93.

Hartung, T., Balls, M., Bardouille, C. et al. (2002). Good cell culture practice. ECVAM Good cell culture practice task force report 1. ATLA 30, 407-414.

Hartung, T., Pazos, P., Gennari, A. et al. (2003). Use of medium supplemented with molecules of plant origin to culture epithelial cells. ALTEX 20, 175-176.

Hatzinger, P. B. and Stevens, J. L. (1989). Rat kidney proximal tubule cells in defined medium: the roles of cholera toxin, extracellular calcium and serum in cell growth and expression of $\gamma$-glutamyl-transferase. In Vitro Cell. Dev. Biol. 25, 205-212.

Hayashi, I. and Sato, G. H. (1976). Replacement of serum by hormones permits growth of cells in a defined medium. Nature 259, 132-134.

Heldin, C.-H., Wasteson, A. and Westermark, B. (1985). Platelet-derived growth factor. Mol. Cell. Endocrinol. 39, 169-187.

Hill, C. S. and Treisman, R. (1995). Transcriptional regulation by extracellular signals: mechansims and specificity. Cell 80, 199-211. 
Holley, R. W. (1975). Control of growth of mammalian cells in cell culture. $\mathrm{Na}$ ture 258, 487-490.

Jarvis, D. L. (1991). Baculovirus expression vectors. A review and update. Ann. N. Y. Acad. Sci. 646, 240-247.

Jayme, D. W. (1999). An animal origin perspective of common constituents of serum-free medium formulations. Dev. Biol. Stand. 99, 181-187.

Jayme, D. W., Epstein, D. A. and Conrad, D. R. (1988). Fetal bovine serum alternatives. Nature 334, 547-548.

Jochems, C. E. A., van der Valk, J. B. F., Stafleu, F. R. and Baumans, V. (2002). The use of fetal bovine serum: ethical or scientific problem? ATLA 30, 219-227.

Klagsbrun, M. (1980). Bovine colostrum supports the serum-free proliferation of epithelial cells but not of fibroblasts in long-term culture. J. Cell Biol. 84, 808-814.

Kleinman, H. K., Luckenbill-Edds, L., Cannon, F. W. and Sephel, G. C. (1987). Use of extracellular matrix components for cell culture. Anal. Biochem. 166, 1-13.

Kyriakis, J. M. and Avruch, J. (2001). Mammalian mitogen-activated protein kinase signal transduction pathways activated by stress and inflammation. Physiol. Rev. 81, 807-869.

Leiderman, L. J., Tucker, J. A. and Dennis, V. W. (1989). Characterization of proliferation and differentiation of Opossum kidney cells in a serum-free defined medium. In Vitro Cell. Dev. Biol. 25, 881-886.

Levi-Montalcini, R. (1987). The nerve growth factor: thirty-five years later. EMBO J. 6, 1145-1154.

Levintow, L. and Eagle, H. (1961). Biochemistry of cultured mammalian cells. Annu. Rev. Biochem. 30, 605-640.

Lindl, T. (2002). Zell- und Gewebekultur. 5. Aufl., Heidelberg, Berlin: Spektrum Akademischer Verlag.

Masters, J. R. W. (2000). Animal Cell Culture. A Practical Approach. $3^{\text {rd }}$ Ed., Oxford University Press.

McKeehan, W. L., Barnes, D., Reid, L. et al. (1990). Frontiers in mammalian cell culture. In Vitro Cell. Dev. Biol. 26, 923.

Merten, O.-W. (1999). Safety issues of animal products used in serum-free media. Dev. Biol. Stand. 99, 167-180.
Morel, F. (1981). Sites of hormone action in the mammalian nephron. Am. J. Physiol. 240, F159-F164.

Morton, H. J. (1979). A survey of commercially available tissue culture media. In Vitro 6, 89-108.

Murray, A. and Hunt, T. (1993). The cell cycle. An introduction. New York, Oxford: Oxford University Press, Inc.

Nardone, R. M. (1987). Cell culture methodology from donor to cell lines. BioTechniques 5, 122-127.

Pakkanen, R. and Neutra, M. (1994). Bovine colostrum ultrafiltrate: an effective supplement of the culture of mouse-mouse hybridoma cells. J. Immunol. Meth. 169, 63-71.

Price, P. J. and Gregory, E. A. (1982). Relationship between in vitro growth promotion and biophysical and biochemical properties of the serum supplement. In Vitro 18, 576-584.

Ross, R., Raines, E. W. and Bowen-Pope, D. F. (1986). The biology of plateletderived growth factor. Cell 46, 155-169.

Schaeffer, W. I. (1990). Terminology associated with cell, tissue and organ culture, molecular biology and molecular genetics. In Vitro Cell. Dev. Biol. 26, 97-101.

Sens, D. A., Detrisac, C. J., Sens, M. A. et al. (1999). Tissue culture of human renal epithelial cells using a defined serum-free growth formulation. Exp. Nephrol. 7, 344-352.

Shah, G. (1999). Why do we still use serum in the production of biopharmaceuticals? Dev. Biol. Stand. 99, 17-22.

Shailer, C. and Corrin, K. (1999). Serum supply: policies and controls operating in New Zealand. Dev. Biol. Stand. 99, 71-77.

Steimer, K. S., Packard, R., Holden, D. and Klagsbrun, M. (1981). The serumfree growth of cultured cells in bovine colostrum and in milk obtained later in the lactation period. J. Cell. Physiol. 109, 223-234.

Strebel, C. und Fischer, R. (2003). Interaktive Datenbank über Arbeiten mit serumfreien Zelllinien. ALTEX 20, 202.

Taub, M. (1990). The use of defined media in cell and tissue culture. Toxicol. in Vitro 4, 213-225.

Taub, M. and Sato, G. (1980). Growth of functional primary cultures of kidney epithelial cells in defined medium. $J$. Cell. Physiol. 105, 369-378.

Taub, M., Chuman, L., Saier, M. H. and Sato, G. (1979). Growth of MadinDarby canine kidney epithelial cell (MDCK) line in hormone-supplemented, serum-free medium. Proc. Natl. Acad. Sci. USA 76, 3338-3342.

van der Valk, J., Mellor, D., Brands, R. et al. (2003). The humane collection of fetal bovine serum and possibilities for serum-free cell and tissue culture. Toxicol. in Vitro 17, in press.

Wang, Y. and Taub, M. (1991). Insulin and other regulatory factors modulate the growth and the phosphoenolpyruvate carboxykinase (PEPCK) activity of primary rabbit kidney proximal tubule cells in serum free medium. $J$. Cell. Physiol. 147, 374-382.

Wessman, S. J. and Levings, R. L. (1999). Benefits and risks due to animal serum used in cell culture production. Dev. Biol. Stand. 99, 3-8.

Widmann, C., Gibson, S., Jarpe, M. B. and Johnson, G. L. (1999). Mitogenactivated protein kinase: conservation of a three-kinase module from yeast to human. Physiol. Rev. 79, 143-180.

Wilson, P. D. and Horster, M. F. (1983). Differential response to hormones of defined distal nephron epithelia in culture. Am. J. Physiol. 244, C166C174.

Wirthensohn, G. and Guder, W. G. (1986). Renal substrate metabolism. Physiol. Rev. 66, 469-497.

Zimmermann, A. M., Vierck, J. L., O'Reilly, B. A. and Dodson, M. V. (2000). Formulation of a defined medium to maintain cell health and viability in vitro. Methods Cell Sci. 22, 43-49.

\section{Correspondence to}

Gerhard Gstraunthaler, Ph.D.

Department of Physiology

University of Innsbruck

Fritz-Pregl-Strasse 3

A-6010 Innsbruck

Phone: +43-512-507 3760

Fax: +43-512-507 2853

e-mail: gerhard.gstraunthaler@uibk.ac.at Web-Site: http://physiologie.uibk.ac.at 